\title{
Nutrient intake in schoolchildren: some practical considerations
}

\author{
BY. G. MCNEILL, L. DAVIDSON, D. C. MORRISON, \\ Rowett Research Institute, Bucksburn, Aberdeen $A B 29 S B$, \\ I. K. CROMBIE AND J. KEIGHRAN \\ Department of Community Medicine, Ninewells Hospital, Dundee DDI $9 S Y$ \\ J. TODMAN \\ Department of Psychology, University of Dundee, Dundee DDI $4 H \mathrm{~N}$
}

The diet of schoolchildren has been a sensitive issue throughout this century. The observation that recruits to the army during the Boer War were below desirable growth standards opened interest in a topic which has never since left the agenda for discussions on nutrition policy in this country. In the last decade concerns have centred on the possibility that dietary habits of schoolchildren, notably their high levels of consumption of sugar and high-fat snack foods and low consumption of fruit, vegetables and fibre, contribute to the development of dental caries and to degenerative diseases later in life. More recently the possibility of inadequacy of the diet of schoolchildren has been brought to the attention of scientists and the public by the publication of a report suggesting that low vitamin and mineral intake may impair mental function (Benton \& Roberts, 1988). It seems as important now as ever before to be able to assess the adequacy of schoolchildren's diets and to identify possible health risks associated with current dietary practices.

In 1983 the Department of Health and Social Security (DHSS) carried out a survey of the dietary habits of 3591 children aged 10-14 years in England, Wales and Scotland (DHSS, 1989), using the $7 \mathrm{~d}$ weighed-intake method. This study provides a benchmark against which future studies will be compared. Other studies are likely to be based on smaller sample sizes and to have access to less resources and manpower than the DHSS survey. Practical aspects of the design and interpretation of such studies need to be considered to optimize the quality and validity of the data collected.

We have recently carried out a survey of dietary intake in 12-year-old schoolchildren in Dundee which has highlighted some of the practical considerations and problems of small-scale dietary studies in schoolchildren. The survey was carried out as an assessment of nutrient intake before a randomized controlled trial of the effects of vitamin and mineral supplements on verbal and non-verbal IQ, the results of which have been reported elsewhere (Crombie et al. 1990). While the primary hypothesis under test did not relate to the level of nutrient intake in the children, the baseline dietary information was seen as essential for the interpretation of the findings of a supplementation study. If a significant effect of supplementation were found, it is useful to know whether the intake of the nutrient under question is below recommended daily allowances (RDA) or whether these require upward revision. Whether an effect of supplementation is found or not, it is also necessary to know whether the intake of the nutrient(s) in question is unusually high or low relative to other groups of children to whom the findings might be considered relevant, and, if conflicting findings between similar studies are found, to determine whether the nutrient intakes of the different study groups explain the differences in the results obtained. 
The children studied for this purpose were the ninety-four first-year secondary school pupils in a Dundee school. The mean age of the children was 12 years 4 months at the time of the dietary survey. Weight-for-age was on average $102 \%$ of the NCHS 50 th centile (World Health Organization, 1983) for boys and 97\% for girls. Equivalent values for height-for-age were $97 \%$ in boys and $99 \%$ in girls. Parents of the children were invited to a meeting in the school to outline the study, and parental consent was required for each child to participate. Due to the requirement to complete the dietary data collection before the start of the randomized controlled trial, all the dietary information was collected in four 1-week periods, with eighteen to twenty-six children studied each week. The dietary data collection was carried out from the base of the school, as there was insufficient time and manpower to visit and instruct the children and parents in their own homes.

For the week of recording, each child was issued with a PETRA electronic scale (Bingham et al. 1985) and a specially designed notebook. Each group of children was given a 40 min period of instruction on the use of the scale by the dietitian (L.D.). The scales were left in a central store during the day except at lunchtime, so snacks had to be recorded in the notebook. The tapes were reviewed by the dietitian on the second and sixth days of the week of recording, and any problems were dealt with when the children came to collect their scales.

The PETRA scales were chosen for the present study rather than the more usual digital scales because it was felt that the children would find it easier to record spoken rather than written information, and because it was hoped that the fact that the scales do not display portion weight to the user would reduce the likelihood of alterations in eating habits. The scales proved robust (only one child had technical problems with the scales) and were popular with the children due to their novelty value. Disadvantages of these scales were the requirement for taring the scales with an empty vessel before each weighing, the need for which is not obvious to the subject, and the possibility that high levels of background noise, e.g. in the school canteen at lunchtime, could drown the recorded voice of the child describing the foods on the tape. However, these problems did not affect large numbers of the records.

The majority of problems encountered in the dietary data collection were problems which are common to all methods used to collect nutritional information in children. The children were not always aware of which variety of a food, e.g. type of spread or milk, they had eaten, although they could usually give very detailed information on the colour and flavour of sweets and snack foods. Sweets and snacks were often local specialities which provided some difficulties in coding from national food tables (Paul \& Southgate, 1978; Tan et al. 1985). For information recorded in the notebooks and for some foods for which no plausible weight was recorded on the PETRA scale, a portion size had to be assumed using values for small portions from a recent publication (Crawley, 1988). This publication is based on data from dietary surveys in adults, and a similar publication based on the DHSS survey of diet in schoolchildren would be a valuable addition to the resources for estimating nutrient intake in schoolchildren. Most importantly, for some children there was evidence of a decline in interest in and diligence of recording over the $7 \mathrm{~d}$ of the study. This was suggested by a tendency to omit meals and snacks from the records as the week progressed, and in some children no dietary information at all was recorded on the later days of the study.

The process of deciding which data to reject has received little attention in literature on dietary methodology. It is usually assumed that a dietitian will recognize implausible 
Table 1. Day-to-day variation in nutrient intake over $7 \mathrm{~d}$ in eighteen 12-year-old girls from Dundee

\begin{tabular}{|c|c|c|c|c|c|c|c|c|c|}
\hline $\begin{array}{l}\text { Day of record } \\
\text { Nutrient }\end{array}$ & $\begin{array}{c}1 \\
\text { Wed }\end{array}$ & $\begin{array}{c}2 \\
\text { Thurs }\end{array}$ & $\begin{array}{c}3 \\
\text { Fri }\end{array}$ & $\begin{array}{c}4 \\
\text { Sat }\end{array}$ & $\begin{array}{c}5 \\
\text { Sun }\end{array}$ & $\begin{array}{c}6 \\
\text { Mon }\end{array}$ & $\begin{array}{c}7 \\
\text { Tue }\end{array}$ & ANOVA* & $\begin{array}{c}\text { Week } \nu . \\
\text { weekend }\end{array}$ \\
\hline Energy $(\mathrm{kJ})$ & 9475 & 9225 & 9100 & 7650 & 8420 & 8415 & 7665 & $P<0.005$ & $P<0.001$ \\
\hline Protein $(\mathrm{g})$ & $60 \cdot 8$ & $62 \cdot 2$ & $53 \cdot 4$ & $49 \cdot 8$ & $63 \cdot 6$ & $62 \cdot 4$ & $54 \cdot 0$ & $P<0.05$ & NS \\
\hline Fat (g) & $99 \cdot 3$ & $94 \cdot 7$ & 97.0 & $83 \cdot 8$ & $87 \cdot 4$ & $90 \cdot 2$ & $82 \cdot 0$ & NS & NS \\
\hline Starch $(g)$ & 152.9 & $165 \cdot 1$ & $149 \cdot 0$ & $126 \cdot 3$ & 128.7 & 159.4 & $138 \cdot 6$ & $P<0.005$ & $P<0.01$ \\
\hline Sugar $(\mathrm{g})$ & $150 \cdot 3$ & $120 \cdot 0$ & $133 \cdot 6$ & 125.9 & $132 \cdot 1$ & $96 \cdot 6$ & $106 \cdot 5$ & $P<0.001$ & NS \\
\hline Fibre (g) & 14.9 & $16 \cdot 1$ & $16 \cdot 6$ & 12.5 & $12 \cdot 1$ & $15 \cdot 7$ & $12 \cdot 6$ & $P<0.05$ & $P<0.02$ \\
\hline Iron (mg) & 9.8 & $11 \cdot 1$ & 10.9 & $8 \cdot 2$ & $12 \cdot 1$ & 11.4 & $9 \cdot 4$ & NS & NS \\
\hline Calcium (mg) & 966 & 974 & 841 & 596 & 796 & 888 & 939 & $P<0.001$ & $P<0.001$ \\
\hline Vitamin $A \ddagger(\mu g)$ & 518 & 1124 & 492 & 1391 & 403 & 451 & 450 & NS & NS \\
\hline Vitamin $C(\mathrm{mg})$ & $30 \cdot 4$ & 39.8 & $31 \cdot 4$ & $34 \cdot 0$ & $24 \cdot 1$ & $27 \cdot 1$ & 21.9 & NS & NS \\
\hline
\end{tabular}

NS, not significant.

* ANOVA of daily values.

$\neq$ Paired $t$ test weekdays $v$. weekend (two-tailed).

$\ddagger$ Retinol equivalents.

records, although the criteria for rejection are rarely discussed. In the present study the records were first reviewed by the dietitian (L.D.), and the days which had an implausible record of foods, on the basis of the pattern of meal and snack intake on earlier days of the week, were noted. The records were then reviewed by a nutritionist who had had no involvement in the study, and using the same criteria she rejected fewer days. All the days rejected by the second nutritionist had also been rejected by L.D., and these were not processed further. After discussion it was decided to reject all days which had been rejected by L.D., with the realization that this might lead to the omission of data from children with the lowest nutrient intakes, and hence an over-estimate of the mean nutrient intake of the group. Children who had only one or two 'satisfactory' days were then excluded from the subsequent data analysis. Using this criterion the records of nineteen of the thirty-seven boys and fourteen of the fifty-seven girls were completely rejected, giving a response rate of $65 \%$ for children with three or more satisfactory days. This is a disappointingly low value when compared with the value of $75 \%$ satisfactory completion of $7 \mathrm{~d}$ weighed records in the DHSS (1989) study. Only $30 \%$ of the children in the present study succeeded in recording $7 \mathrm{~d}$ which were accepted by both the dietitian and nutritionist, suggesting that a smaller number of days may be a more realistic aim when manpower for surveys is limited. An alternative is to use diary-interview methods which have been found by one group to produce little fatigue in repeated use (Hackett et al. 1985).

The accepted records were analysed by the Microdiet programme (Bassham \& Fletcher, 1985), and the mean nutrient intake for each child was used to calculate the arithmetic mean for the intake for each nutrient for boys and girls. The values for several of the micronutrients are limited by the missing values for the content of these nutrients in certain foods in the UK food composition database (Paul \& Southgate, 1978), notably zinc and folate, but in this respect the results of the present study are comparable with those from other studies calculated from the same database. To give information on the variability of nutrient intake over the week, Table 1 shows the mean values for the intake 
Table 2. Nutrient intakes of 12-year-old boys from Dundee compared with published values $(n=18)$

(Mean values and standard deviations)

\begin{tabular}{|c|c|c|c|c|c|c|}
\hline Nutrient & Mean & SD & $\begin{array}{c}\text { Recommended } \\
\text { intake } \\
\text { (DHSS, 1979)* }\end{array}$ & $\begin{array}{l}\text { DHSS }(1979)^{*} \\
\text { Scotland }\end{array}$ & $\begin{array}{l}\text { DHSS }(1979)^{*} \\
\text { London } \\
\text { and SE }\end{array}$ & $\begin{array}{c}\text { Benton \& } \\
\text { Roberts } \\
(1988)^{\dagger}\end{array}$ \\
\hline Energy (kJ) & 8960 & 1180 & $9681 \div$ & 8590 & 8790 & 7272 \\
\hline Protein $(\mathrm{g})$ & 61 & 15 & 66 & 62 & 61 & 62 \\
\hline Fat $(\mathrm{g})$ & 93 & 18 & $80 \$$ & 87 & 88 & 58 \\
\hline Starch $(\mathrm{g})$ & 163 & 25 & $295 \S$ & $\mathrm{n} / \mathrm{a}$ & $\mathrm{n} / \mathrm{a}$ & $n / a$ \\
\hline Sugar $(g)$ & 117 & 28 & $43 \S$ & $\mathrm{n} / \mathrm{a}$ & $\mathbf{n} / \mathbf{a}$ & $n / a$ \\
\hline Fibre $(\mathrm{g})$ & 16 & 5 & $25 \S$ & $\mathrm{n} / \mathrm{a}$ & $n / a$ & $\mathrm{n} / \mathrm{a}$ \\
\hline Iron (mg) & 10 & 2 & 12 & 10 & 10 & 9 \\
\hline Calcium (mg) & 822 & 197 & 700 & 880 & 850 & 670 \\
\hline Zinc (mg) & 8 & 2 & 15 & $\mathrm{n} / \mathrm{a}$ & $n / a$ & 6 \\
\hline Magnesium (mg) & 232 & 59 & 3501 & $n / a$ & $\mathrm{n} / \mathrm{a}$ & 200 \\
\hline Phosphorus (g) & $1 \cdot 1$ & 0.2 & $1 \cdot 2$ & $\mathrm{n} / \mathrm{a}$ & $n / a$ & $1 \cdot 0$ \\
\hline Vitamin $A(\mu \mathrm{g})^{* *}$ & 494 & 268 & 725 & 620 & 840 & 1812 \\
\hline Vitamin $B_{1}(\mathrm{mg})$ & 1.2 & 0.4 & $1 \cdot 1$ & $1 \cdot 2$ & $1 \cdot 2$ & 1.4 \\
\hline Vitamin $\mathbf{B}_{2}(\mathrm{mg})$ & 1.5 & $0 \cdot 4$ & 1.4 & $1 \cdot 7$ & $1 \cdot 7$ & 1.7 \\
\hline Vitamin $B_{3}(\mathrm{mg}) \dagger \dagger$ & 27 & $6 \cdot 5$ & 16 & 27 & 26 & $\mathrm{n} / \mathrm{a}$ \\
\hline Vitamin $B_{6}(\mathrm{mg})$ & $1 \cdot 1$ & 0.4 & $1 \cdot 6^{1}$ & $1 \cdot 1$ & 1.2 & 1.6 \\
\hline Vitamin $B_{12}(\mu \mathrm{g})$ & $2 \cdot 8$ & 0.9 & $2 \cdot 0^{r}$ & $n / a$ & $\mathrm{n} / \mathrm{a}$ & $6 \cdot 0$ \\
\hline Folate $(\mu \mathrm{g})^{+}+$ & 105 & 35 & 300 & $\mathrm{n} / \mathrm{a}$ & $n / a$ & 242 \\
\hline Vitamin $\mathrm{C}(\mathrm{mg})$ & 47 & 32 & 25 & 43 & 56 & 126 \\
\hline Vitamin D $(\mu \mathrm{g})$ & $2 \cdot 0$ & $1 \cdot 3$ & $2 \cdot 5^{\circ}$ & 1.2 & 1.4 & $4 \cdot 4$ \\
\hline Vitamin E (mg) & 4.8 & $1 \cdot 4$ & 81 & $\mathrm{n} / \mathrm{a}$ & $\mathbf{n} / \mathbf{a}$ & $6 \cdot 3$ \\
\hline
\end{tabular}

DHSS, Department of Health and Social Security; n/a, not available.

* Values for 10-11-year-olds.

- Values which used 3 d dietary records and a US food composition database.

$\ddagger$ Food and Agriculture Organization/World Health Organization/United Nations University (1985).

$\$$ Derived from National Advisory Committee on Nutrition Education (1983).

|| National Academy of Sciences/National Research Council (1974).

I. World Health Organization (1970).

** Retinol equivalent.

$\dagger$ Nicotinic acid equivalent.

接 Total folate.

of ten nutrients for the eighteen girls for whom $7 \mathrm{~d}$ were accepted. As all records began on a Wednesday, this data also reflects changes in intake over the week of recording. Also shown are the significance levels of the day-to-day variation from analysis of variance, and of the comparison of weekday $v$. weekend days by paired $t$ test. Energy and calcium intakes showed clear day-to-day variations with lower intakes at the weekend than during the week, while sugar and fibre intakes showed significant day-to-day variations but no strong weekday $v$. weekend effect. In the smaller group of ten boys for wnom $7 \mathrm{~d}$ were accepted, no nutrients showed day-to-day variation or weekday $v$. weekend differences which were significant at the $1 \%$ level.

Tables 2 and 3 show the average nutrient intakes of boys and girls in relation to recommended practices (DHSS, 1979; National Advisory Committee on Nutrition 
Table 3. Nutrient intakes of 12-year-old girls from Dundee compared with published values $(n=43)$

(Mean values and standard deviations)

\begin{tabular}{|c|c|c|c|c|c|c|}
\hline Nutrient & Mean & SD & $\begin{array}{l}\text { Recommended } \\
\text { intake } \\
\text { (DHSS, 1979)* }\end{array}$ & $\begin{array}{c}\text { DHSS }(1979)^{*} \\
\quad \text { Scotland }\end{array}$ & $\begin{array}{c}\text { DHSS }(1979)^{*} \\
\text { London } \\
\text { and SE }\end{array}$ & $\begin{array}{c}\text { Benton \& } \\
\text { Roberts } \\
(1988) \dagger\end{array}$ \\
\hline Energy $(\mathrm{kJ})$ & 8140 & 536 & $8595 \ddagger$ & 7640 & 7690 & 7590 \\
\hline Protein (g) & 55 & 9 & 53 & 54 & 53 & 62 \\
\hline Fat $(\mathrm{g})$ & 85 & 17 & $70 \S$ & 79 & 80 & 56 \\
\hline Starch $(\mathrm{g})$ & 143 & 29 & $262 \S$ & $\mathrm{n} / \mathrm{a}$ & $\mathrm{n} / \mathrm{a}$ & $\mathrm{n} / \mathrm{a}$ \\
\hline Sugar $(g)$ & 110 & 34 & $38 \S$ & $\mathrm{n} / \mathrm{a}$ & $\mathbf{n} / \mathbf{a}$ & $\mathrm{n} / \mathrm{a}$ \\
\hline Fibre $(\mathrm{g})$ & 15 & 4 & $25 \S$ & $\mathrm{n} / \mathrm{a}$ & $\mathrm{n} / \mathrm{a}$ & $\mathrm{n} / \mathrm{a}$ \\
\hline Iron (mg) & 10 & 5 & 12 & 9 & 9 & 4 \\
\hline Calcium (mg) & 767 & 191 & 700 & 740 & 700 & 672 \\
\hline Zinc (mg) & 7 & 1 & $15^{\|}$ & $\mathrm{n} / \mathrm{a}$ & $\mathbf{n} / \mathbf{a}$ & 7 \\
\hline Magnesium (mg) & 205 & 44 & $300^{\prime}$ & $\mathrm{n} / \mathrm{a}$ & $\mathbf{n} / \mathbf{a}$ & 236 \\
\hline Phosphorus (g) & $1 \cdot 0$ & $0 \cdot 2$ & $1 \cdot 2$ & $\mathrm{n} / \mathrm{a}$ & $\mathrm{n} / \mathrm{a}$ & $1 \cdot 0$ \\
\hline Vitamin $A(\mu g)^{* *}$ & 510 & 480 & 725 & 590 & 700 & 1813 \\
\hline Vitamin $B_{1}(\mathrm{mg})$ & $1 \cdot 0$ & 0.3 & 0.9 & $1 \cdot 0$ & $1 \cdot 0$ & 1.5 \\
\hline Vitamin $B_{2}(\mathrm{mg})$ & $1 \cdot 4$ & 0.5 & $1 \cdot 4$ & $1 \cdot 4$ & 1.4 & $1 \cdot 7$ \\
\hline Vitamin $B_{3}(\mathrm{mg}) \dagger \dagger$ & 24 & 4 & 16 & 23 & 23 & $\mathbf{n} / \mathbf{a}$ \\
\hline Vitamin $B_{6}(\mathrm{mg})$ & $1 \cdot 0$ & 0.2 & $1 \cdot 6^{\prime}$ & $\mathrm{n} / \mathrm{a}$ & $\mathrm{n} / \mathrm{a}$ & $1 \cdot 5$ \\
\hline Vitamin $B_{12}(\mu g)$ & 3 & 2 & 29 & $\mathrm{n} / \mathrm{a}$ & $\mathrm{n} / \mathrm{a}$ & 3 \\
\hline Folate $(\mu g) \ddagger \ddagger$ & 90 & 22 & 300 & $\mathrm{n} / \mathrm{a}$ & n/a & 250 \\
\hline Vitamin C (mg) & 28 & 11 & 25 & 41 & 56 & 133 \\
\hline Vitamin D $(\mu g)$ & $1 \cdot 8$ & 0.9 & $2 \cdot 5 !$ & $1 \cdot 2$ & $1 \cdot 2$ & $3 \cdot 2$ \\
\hline Vitamin E (mg) & $4 \cdot 8$ & $1 \cdot 1$ & $8:$ & $n / a$ & $\mathrm{n} / \mathrm{a}$ & 9.7 \\
\hline
\end{tabular}

DHSS, Department of Health and Social Security; n/a, not available.

* Values for 10-11-year-olds.

$\uparrow$ Values which used 3 d dietary records and a US food composition database.

$\ddagger$ Food and Agriculture Organization/World Health Organization/United Nations University (1985).

$\$$ Derived from National Advisory Committee on Nutrition Education (1983).

National Academy of Sciences/National Research Council (1974).

I World Health Organization (1970).

** Retinol equivalent.

t+ Nicotinic acid equivalent.

$\ddagger \ddagger$ Total folate.

Education, 1983) and to the intakes recorded in the DHSS (1989) survey and in a previous study of the effect of vitamin and mineral supplementation on IQ (Benton \& Roberts, 1988). Comparison of the values between studies is limited by the fact that different studies have presented data for different nutrients, but three main findings emerge. First, compared with recommendations, the nutrient intakes of fat and sugar are high and those of starch and fibre are low, but in this respect the values are similar to those recorded in a number of studies in adults, and the proportion of energy derived from fat (39\% for both boys and girls) is very similar to that seen in children of the DHSS (1989) survey. Second, the nutrient intakes of the children in Dundee are very similar to those of the DHSS (1989) survey apart from the slightly higher Ca intake in the Dundee girls, and the lower vitamin $\mathrm{A}$ and higher vitamin $\mathrm{D}$ intake in both boys and girls from 
Table 4. Sources of nutrients by food group for 12-year-old boys and girls from Dundee

(Mean values for boys and girls expressed as a percentage of nutrient derived from food group)

\begin{tabular}{lrrrrrrrrrr}
\hline & B and R & Cer & P and $\mathrm{R}$ & Pot & Dai & M and F & O and F & C and S F and V \\
\hline Energy & 13 & 4 & 3 & 16 & 12 & 16 & 3 & 29 & 4 \\
Protein & 15 & 4 & 3 & 8 & 22 & 32 & 0 & 10 & 5 \\
Fat & 6 & 1 & 2 & 17 & 17 & 25 & 7 & 22 & 3 \\
Fibre & 20 & 13 & 2 & 32 & 0 & 0 & 0 & 10 & 23 \\
Sugar & 2 & 2 & 2 & 1 & 4 & 0 & 0 & 80 & 9 \\
Iron & 19 & 8 & 2 & 13 & 5 & 24 & 0 & 18 & 10 \\
Calcium & 14 & 1 & 4 & 3 & 49 & 7 & 0 & 17 & 4 \\
Vitamin A & 2 & 0 & 3 & 0 & 35 & 13 & 16 & 17 & 13 \\
Vitamin C & 0 & 0 & 0 & 46 & 13 & 2 & 0 & 8 & 30 \\
\hline \hline
\end{tabular}

B and R, bread and rolls; Cer, other cereals; $\mathrm{P}$ and $\mathrm{R}$, pasta and rice; Pot, potatoes (including crisps and chips); Dai, dairy products and eggs; $M$ and $F$, meat, meat products and fish; $O$ and $F$, oils, fats and spreads; $C$ and $S$, confectionery. cakes and sweet drinks; $F$ and $V$, fruit, vegetables and nuts.

Dundee. The striking difference between the vitamin A intakes may reflect the fact that the school studied was in a lower income area of Dundee, as the DHSS (1989) data for the UK as a whole show lower intakes of vitamin A in lower socio-economic groups. Third, when the data on intake of fourteen micronutrients is compared with the reported nutrient intakes of children in the Welsh study (Benton \& Roberts, 1988), the Dundee children in the present study are seen to have similar or lower intakes of all micronutrients except for $\mathrm{Fe}$ in girls and $\mathrm{Ca}$ in both boys and girls.

If the nutrient intake data of these children is to form the basis of dietary advice, it is useful to analyse the data in terms of the proportion of nutrients provided by different food groups. These values were very similar for boys and girls, and Table 4 shows the mean values for percentage of nutrients derived from different food groups. The high proportion of energy and sugar provided by confectionery is striking, but the proportion of energy derived from confectionery is very similar to the value of $28 \%$ of energy derived from sweets, biscuits and puddings in a survey of adolescents in Glasgow in 1964 and 1971 (Durnin et al. 1974). It may be important to consider the possibility that the actual nutrient intake of children is not greatly different from that of children in previous decades or from the present-day adult population even though the foods from which these nutrients are derived are very different.

The authors would like to thank the staff and the children of the school for their co-operation in this study, Dr Ann Ralph for checking the dietary records and the Scottish Hospitals Endowment Research Trust for financial support.

\section{REFERENCES}

Bassham, S. \& Fletcher, L. R. (1985). Calculation of nutrient intake by microcomputer. Proceedings of the Nutrition Society 44, 36A.

Benton, D. \& Roberts, G. (1988). Effect of vitamin and mineral supplementation on intelligence of a sample of schoolchildren. Lancet i, 140-143.

Bingham, S. A., Cummings, J. H. \& Murgatroyd, P. R. (1985). PETRA: A new device for weighed dietary records. 13th International Congress of Nutrition, p. 126 (Abstract). London: John Libbey. 
Crawley, H. (1988). Food Portion Sizes. London: H.M. Stationery Office.

Crombie, I. C., Todman, J., McNeill, G., Florey, C. DuV., Menzics. I. \& Kennedy, R. A. (1990). Effect of vitamin and mineral supplementation on verbal and non-verbal reasoning of schoolchildren. Lancet $\mathbf{i}$, 744-747.

Department of Health and Social Security (1979). Recommended Daily Amounts of Food, Energy and Nutrients for Groups of People in the United Kingdom. London: H.M. Stationery Office.

Department of Health and Social Security (1989). The Diets of British Schoolchildren. Report on Health and Social Subjects no. 36. London: H.M. Stationery Office.

Durnin, J. V. G. A., Lonergan, M. E., Good, J. \& Ewan, A. (1974). A cross-sectional nutritional and anthropometric study, with an interval of 7 years, on 611 young adolescent schoolchildren. British Journal of Nutrition 32, 169-179.

Food and Agriculture Organization/World Health Organization/United Nations University (1985). Energy and Protein Requirements. Report Series no. 724. Geneva: WHO.

Hackett, A. F., Appleton, D. R., Rugg-Gunn, A. J. \& Eastoc, J. E. (1985). Some influences on the measurement of food intake during a dietary survey of adolescents. Human Nutrition: Applied Nutrition 39A, 167-177.

National Academy of Sciences/National Research Council (1974). Recommended Daily Dietary Allowances. Washington, DC: Food and Nutrition Board.

National Advisory Committee on Nutrition Education (1983). A Discussion Paper on Proposals for Nutritional Guidelines for Health Education in Britain. London: Health Education Council.

Paul, A. A. \& Southgatc, D. A. T. (1978). McCance and Widdowson's The Composition of Fonds, 4th ed. London: H.M. Stationery Office.

Tan, S. P.. Wenlock. R. W. \& Buss, D. H. (1985). Immigrant Foods. McCance and Widdow'son's The Composition of Foods, 2nd Suppl. London: H.M. Stationery Office.

World Health Organization (1970). Requirements of Ascorbic Acid, Vitamin D, Vitamin B12, Folate and Iron. Technical Report Series no. 452. Geneva: WHO.

World Health Organization (1983). Measuring Change in Nutritional Status. Geneva: WHO. 